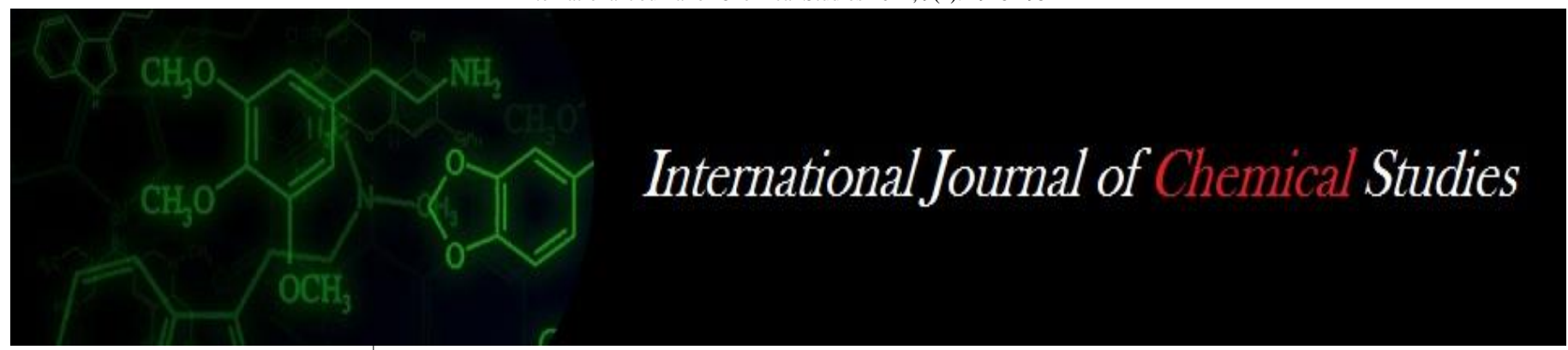

P-ISSN: 2349-8528

E-ISSN: 2321-4902

www.chemijournal.com

IJCS 2021; 9(1): 2948-2951

(C) 2021 IJCS

Received: 01-10-2020

Accepted: 12-12-2020

\section{DS Potdar}

Department of Soil Science and

Agricultural Chemistry,

Mahatma Phule Krishi

Vidyapeeth, Rahuri,

Maharashtra, India

\section{HS Purohit}

Department of Soil Science and Agricultural Chemistry,

Rajasthan College of Agriculture, Udaipur, Rajasthan, India

\section{RH Meena}

Department of Soil Science and Agricultural Chemistry,

Rajasthan College of Agriculture,

Udaipur, Rajasthan, India

\section{KC Ombase}

Department of Agronomy;

Mahatma Phule Krishi

Vidyapeeth, Rahuri,

Maharashtra, India

\section{Effect of phosphorus and biofertilizers with and without FYM on mustard and soil fertility}

\author{
DS Potdar, HS Purohit, RH Meena and KC Ombase
}

DOI: $\underline{\text { https://doi.org/10.22271/chemi.2021.v9.i1ao.11678 }}$

\begin{abstract}
A field experiment was conducted at Rajasthan College of Agriculture, Udaipur to study the effect of integrated phosphorus management on yield and quality of mustard and soil fertility. The experiment was laid out in split plot design with four levels of phosphorus $\left(0,20,40\right.$ and $\left.60 \mathrm{~kg} \mathrm{P}_{2} \mathrm{O}_{5} \mathrm{ha}^{-1}\right)$, two levels of FYM (0 and $\left.5 \mathrm{t} \mathrm{ha}^{-1}\right)$ and four levels of microbial inoculum (no inoculum, PSB, VAM and PSB + VAM). The maximum seed and straw yield of mustard was significantly enhanced with $60 \mathrm{~kg} \mathrm{P}_{2} \mathrm{O}_{5} \mathrm{ha}^{-1}, 5 \mathrm{t} \mathrm{FYM}$ $\mathrm{ha}^{-1}$ and PSB + VAM inoculation. Significantly higher available N, P, K and S content in soil after harvest of mustard was reported with $60 \mathrm{~kg} \mathrm{P}_{2} \mathrm{O}_{5} \mathrm{ha}^{-1}, 5 \mathrm{t} \mathrm{FYM} \mathrm{ha}^{-1}$ and PSB + VAM inoculation. Integrated application of $60 \mathrm{~kg} \mathrm{P}_{2} \mathrm{O}_{5} \mathrm{ha}^{-1}+5 \mathrm{t} \mathrm{FYM} \mathrm{ha}^{-1}$ reported significantly higher seed yield, straw yield, oil yield and available $\mathrm{P}$ and $\mathrm{S}$ after harvest of mustard. Application of $5 \mathrm{t} \mathrm{FYM} \mathrm{ha}^{-1}$ along with PSB + VAM inoculation reported significantly higher available P.
\end{abstract}

Keywords: Mustard, phosphorus, FYM, PSB, VAM and biofertilizers

\section{Introduction}

Mustard, an important oil seed crop of India, is mainly cultivated in the states of Rajasthan, Uttar Pradesh, Hariyana, Madhya Pradesh and Gujarat. Mustard oil is an important component of the diet of northern and eastern parts of India. The mustard cake is used mostly for cattle feed and manure. Green stem and leaves are a good source of fodder for cattle.

Although it is major oil seed crop but its productivity is quite low due to imbalanced and inadequate supply of nutrients and poor fertility status of soils. The soils of this region are deficient not only in nitrogen but phosphorus and sulphur also. About 98 percent of the cultivated soils of India need phosphorus fertilization for good yield (Luthura et al. 1983) ${ }^{[9]}$.

Phosphorus is necessary for Maintaince and transmission of energy, transfer of genetic characteristics and beneficial for root development, vigorous growth, better yield and quality and nodule formation in legume crops. Phosphorus fixation is the major problems in productivity of crops concerning not only its actual deficiency in soil but also its availability to crop plants. Approximately 15-20 per cent of applied fertilizer phosphorus is utilized by the crops and rest of the gets fixed in the soil (Toro, 2007) ${ }^{[15]}$. For enhancing availability and reducing the fixation of phosphorus, integrated phosphorus management (IPM) is the only viable strategy. In order to bring the soil well supplied with all essential plant nutrients and also to maintain good soil health it is necessary to use organic source like FYM, biofertilizers as PSB and VAM along with inorganic fertilizers. It not only enhances the phosphorus availability to crop plants, but reduce fixation, release the fixed form of phosphorus and improves the soil fertility (Arbad and Ismail, 2011) ${ }^{[1]}$. The experiment was, therefore conducted to study the effect of integrated phosphorus management on productivity of mustard, quality, nutrient uptake and fertility status.

\section{Materials and Methods}

The experiment was conducted during rabi 2016-17 and 2017-18 at Rajasthan College of Agriculture, (MPUAT) Udaipur. The soil of the experimental plot was clay loam in texture and alkaline in reaction having $\mathrm{pH}$ (7.98 and 8.05), organic carbon (0.67 and $0.71 \%)$, and the available $\mathrm{N}$ (261.6 and $\left.270.1 \mathrm{~kg} \mathrm{ha}^{-1}\right), \mathrm{P}\left(21.06\right.$ and $\left.19.48 \mathrm{~kg} \mathrm{ha}^{-1}\right)$ and $\mathrm{K}(287.1$ and $308.4 \mathrm{~kg}$ $\mathrm{ha}^{-1}$ ), respectively in the year 2016-17 and 2017-18. The treatments consisted of four levels of phosphorus $\left(0,20,40\right.$ and $\left.60 \mathrm{~kg} \mathrm{P}_{2} \mathrm{O}_{5} \mathrm{ha}^{-1}\right)$, two levels of FYM $\left(0\right.$ and $\left.5 \mathrm{t} \mathrm{FYM} \mathrm{ha}^{-1}\right)$ as main 
plot treatments and four levels of microbial inoculum (no inoculum, PSB, VAM and PSB + VAM) as sub plot treatments.

Required quantity of FYM was incorporated as per the treatment. Full dose of $\mathrm{P}$ and half dose of nitrogen fertilizers were drilled just before the sowing in the form of urea and DAP and remaining half dose of nitrogen was applied 30 days after sowing. Inoculum of VAM, Glomus fasciculatum was drilled below seed in soil and the seeds were inoculated with Bacillus megatherium var. phosphaticum for PSB as per treatment. The observation of growth parameters and yield attributes and yields were recorded at the time of harvest. At harvest of crops, soil samples were analyzed for available $\mathrm{N}$, $\mathrm{P}, \mathrm{K}$ and $\mathrm{S}$ as per standard laboratory method.

\section{Result and Discussion \\ Yield and quality}

Application of phosphorus @ $60 \mathrm{~kg} \mathrm{P}_{2} \mathrm{O}_{5} \mathrm{ha}^{-1}$ resulted in the significantly higher seed yield, straw yield and oil content (18.70 $\mathrm{q} \mathrm{ha}^{-1}, 48.31 \mathrm{q} \mathrm{ha}^{-1}$ and 38.05 per cent, respectively) over control and it was at par with $40 \mathrm{~kg} \mathrm{P}_{2} \mathrm{O}_{5} \mathrm{ha}^{-1}$ in pooled analysis (Table 1). The mustard seed oil yield was significantly improved with application of $60 \mathrm{~kg} \mathrm{P}_{2} \mathrm{O}_{5} \mathrm{ha}^{-1}$ over rest of the phosphorus levels (Table 1). The increased supply of phosphorus might have helped in early root initiation and establishment of the crop (Gangwal et al., 2011) [4]. Application of phosphorus favorably influenced the photosynthesis, biosynthesis of proteins and phospholipids and other metabolic processes of the plant. These results are in conformity with Chouksey et al. (2017) ${ }^{[3]}$.

Significantly the highest seed and straw yield was reported by application of FYM @ $5 \mathrm{t} \mathrm{ha}^{-1}$ (18.65 q ha' and $48.97 \mathrm{q} \mathrm{ha}^{-1}$, respectively) which was enhanced by 28.89 and 30.59 per cent, respectively over no FYM. The increase in yield might be due to higher availability of nutrients under FYM application. The oil content and oil yield of mustard was enhanced by 1.23 and 30.37 per cent with FYM @ $5 \mathrm{t} \mathrm{ha}^{-1}$ over control (Table 1). The gradual release and steady supply of plant nutrients from FYM throughout the growth and development of plants maintained the photosynthetic efficiency and production of metabolites at higher level. These conclusions are in consonance with Pathak and Pal $(2016)^{[10]}$.

The seed and straw yield of mustard was significantly higher with PSB + VAM inoculation and it was enhanced by 11.22 and 13.93 per cent, respectively over no inoculation. The oil content in seed was not influenced significantly with inoculation treatments. Oil yield was significantly enhanced with PSB+VAM inoculation no inoculation and found at par with PSB inoculation (Table 1). This might be attributed due to the solublization of native as well as applied phosphorus and enhanced $\mathrm{P}$ uptake by phosphate solubilizing microorganisms and VAM (Somani, 2004) ${ }^{[13]}$. These findings of present investigations are supported by Lingaraju, 2016) ${ }^{[8]}$ who observed increase in seed and stover yield of mustard due PSB and VAM inoculation.

Integrated application of $60 \mathrm{~kg} \mathrm{P}_{2} \mathrm{O}_{5} \mathrm{ha}^{-1}$ along with 5 t FYM $\mathrm{ha}^{-1}$ recorded significantly higher seed yield $\left(20.37 \mathrm{q} \mathrm{ha}^{-1}\right)$, straw yield (53.33 q ha-1) and oil yield $\left(780.75 \mathrm{~kg} \mathrm{ha}^{-1}\right)$ of mustard, however they were at par with $40 \mathrm{~kg} \mathrm{P}_{2} \mathrm{O}_{5}$ ha $^{-1}$ along with $5 \mathrm{t} \mathrm{FYM} \mathrm{ha}^{-1}$ (Table 2). These results are in accordance with Kumar et al. (2017) [7] who observed combined application of phosphorus and FYM had synergistic effect in increasing seed and straw yield of mustard.

Table 1: Effect of phosphorus, FYM and microbial inoculum on seed yield, Straw yield, oil content and oil yield of mustard (Mean of 2 years)

\begin{tabular}{|c|c|c|c|c|}
\hline Treatments & Seed yield $\left(q\right.$ ha $\left.^{-1}\right)$ & Straw yield $\left(q\right.$ ha $\left.^{-1}\right)$ & Oil content $(\%)$ & Oil yield $\left(\mathrm{kg} \mathrm{ha}^{-1}\right)$ \\
\hline \multicolumn{5}{|c|}{ Phosphorus levels $\left(\mathrm{P}_{2} \mathrm{O}_{5} \mathrm{~kg} \mathrm{ha}^{-1}\right)$} \\
\hline 0 & 13.75 & 35.75 & 37.41 & 515.25 \\
\hline 20 & 16.06 & 42.01 & 37.73 & 606.42 \\
\hline 40 & 17.74 & 46.86 & 37.98 & 674.08 \\
\hline 60 & 18.70 & 48.31 & 38.15 & 713.60 \\
\hline S.Em+ & 0.43 & 0.69 & 0.20 & 11.72 \\
\hline $\mathrm{CD}$ at $5 \%$ & 1.23 & 2.00 & 0.56 & 33.77 \\
\hline \multicolumn{5}{|l|}{ FYM levels $\left(\mathrm{t} \mathrm{ha}^{-1}\right)$} \\
\hline 0 & 14.47 & 37.50 & 37.58 & 544.63 \\
\hline 5 & 18.65 & 48.97 & 38.05 & 710.04 \\
\hline S.Em+ & 0.30 & 0.49 & 0.15 & 8.29 \\
\hline $\mathrm{CD}$ at $5 \%$ & 0.87 & 1.41 & 0.42 & 23.88 \\
\hline \multicolumn{5}{|c|}{ Microbial inoculum } \\
\hline No inoculation & 15.60 & 39.98 & 37.75 & 589.89 \\
\hline PSB & 16.77 & 44.03 & 37.83 & 635.71 \\
\hline VAM & 16.53 & 43.32 & 37.82 & 626.07 \\
\hline PSB + VAM & 17.35 & 45.55 & 37.86 & 657.67 \\
\hline S.Em+ & 0.19 & 0.53 & 0.11 & 10.76 \\
\hline $\mathrm{CD}$ at $5 \%$ & 0.53 & 1.49 & NS & 30.33 \\
\hline
\end{tabular}

Table 2: Interaction effect of phosphorus and FYM on seed yield, straw yield and oil yield of mustard (Mean of 2 years)

\begin{tabular}{|c|c|c|c|c|c|c|}
\hline \multirow{2}{*}{$\begin{array}{l}\text { Phosphorus levels } \\
\left(\mathrm{P}_{2} \mathrm{O}_{5} \mathrm{~kg} \mathrm{ha}^{-1}\right)\end{array}$} & \multicolumn{2}{|c|}{$\begin{array}{l}\text { Seed yield }\left(\mathrm{q} \mathrm{ha}^{-1}\right) \\
\text { FYM levels }\left(\mathrm{t} \mathrm{ha}^{-1}\right)\end{array}$} & \multicolumn{2}{|c|}{$\begin{array}{l}\text { Straw yield }\left(\mathrm{q} \mathrm{ha}^{-1}\right) \\
\text { FYM levels }\left(\mathrm{t} \mathrm{ha}^{-1}\right)\end{array}$} & \multicolumn{2}{|c|}{$\begin{array}{c}\text { Oil yield }\left(\mathrm{kg} \mathrm{ha}^{-1}\right) \\
\text { FYM levels }\left(\mathrm{t} \mathrm{ha}^{-1}\right)\end{array}$} \\
\hline & 0 & a 5 & O & 5 & 0 & na 5 \\
\hline 0 & 10.63 & 16.87 & 28.44 & 43.06 & 395.18 & 635.32 \\
\hline 20 & 14.29 & 17.83 & 36.62 & 47.41 & 535.87 & 676.97 \\
\hline 40 & 15.93 & 19.54 & 41.64 & 52.08 & 601.04 & 747.13 \\
\hline 60 & 17.03 & 20.37 & 43.28 & 53.33 & 646.46 & 780.75 \\
\hline S.Em+ & \multicolumn{2}{|c|}{0.60} & \multicolumn{2}{|c|}{0.98} & \multicolumn{2}{|c|}{16.58} \\
\hline $\mathrm{CD}$ at $5 \%$ & \multicolumn{2}{|c|}{1.74} & \multicolumn{2}{|c|}{2.83} & \multicolumn{2}{|c|}{47.75} \\
\hline
\end{tabular}




\section{Soil fertility}

The post harvest available $\mathrm{N}, \mathrm{P}, \mathrm{K}$ and $\mathrm{S}$ content of soil was significantly higher with application of $60 \mathrm{~kg} \mathrm{P}_{2} \mathrm{O}_{5} \mathrm{ha}^{-1}$ over control and at par with $40 \mathrm{~kg} \mathrm{P}_{2} \mathrm{O}_{5} \mathrm{ha}^{-1}$ (Table 3). The highest available N, P, K and S (267.43, 21.1, 309.35 and $9.94 \mathrm{~kg} \mathrm{ha}^{-}$ ${ }^{1}$, respectively) in soil was recorded with $60 \mathrm{~kg} \mathrm{P}_{2} \mathrm{O}_{5} \mathrm{ha}^{-1}$. The increased soil nutrient status might be due to enhanced enzymatic activities in soil and soil microbial activity as a result of phosphorus application. The similar results were observed by Solanki et al. $(2015)^{[12]}$.

Incorporation of $5 \mathrm{t} \mathrm{FYM} \mathrm{ha}^{-1}$ significantly improved the available $\mathrm{N}, \mathrm{P}, \mathrm{K}$ and $\mathrm{S}$ content of soil after harvest of mustard over no FYM (Table 4). The available N, P, K and S content of soil after harvest of mustard was enhanced by 8.86 , 10.94, 744 and 19.35 per cent respectively over no FYM. The increase in available nutrients in soil after harvest of crop might be due to direct addition and slow release of nutrients from FYM added to soil, reduction in nutrient fixation in soil and release of fixed nutrients by the organic acids produced during decomposition of FYM (Tandon, 1987) ${ }^{[14]}$. These results are in conformity with the earlier findings of Singh et al. $(2015)^{[11]}$.

Duel inoculation of PSB+VAM reported significantly higher available $\mathrm{N}, \mathrm{P}, \mathrm{K}$ and $\mathrm{S}$ over no inoculation, however available $\mathrm{N}$ and $\mathrm{S}$ was at par with PSB inoculation (Table 3). Enhanced available nutrient status of soil with PSB+VAM inoculation might be due to release of organic acids and enzymes and remobilization of fixed nutrients by PSB and VAM in soil and resulted in suitable conditions in rhizosphere. The findings are in close agreement with those obtained by Khandelwal et al. (2012) ${ }^{[6]}$.

Integrated application of $60 \mathrm{~kg} \mathrm{P}_{2} \mathrm{O}_{5} \mathrm{ha}^{-1}+5 \mathrm{t} \mathrm{FYM} \mathrm{ha-1}$ reported significantly higher available phosphorus $(21.70 \mathrm{~kg}$ $\mathrm{ha}^{-1}$ ) after harvest of mustard and it was at par with $40 \mathrm{~kg}$ $\mathrm{P}_{2} \mathrm{O}_{5} \mathrm{ha}^{-1}+5 \mathrm{t} \mathrm{FYM} \mathrm{ha}^{-1}\left(21.50 \mathrm{~kg} \mathrm{ha}^{-1}\right)$ in pooled analysis (Table 4). Release of nutrients with decomposition of FYM and solubilization of unavailable nutrients due to organic acids might have helped in increasing the nutrient status of soil. The favorable effect of FYM in conjunction with chemical fertilizers in enhancing the availability of $\mathrm{P}$ in soil was also reported by Chesti et al. (2013) ${ }^{[2]}$.

The available phosphorus content in soil after harvest of mustard was significantly influenced for FYM and microbial inoculum interaction (Table 5). Application of $5 \mathrm{t} \mathrm{FYM} \mathrm{ha-1}$ alongwith duel inoculation of PSB+VAM reported significantly higher available phosphorus $\left(21.70 \mathrm{~kg} \mathrm{ha}^{-1}\right)$ which was at par with $5 \mathrm{t} \mathrm{FYM} \mathrm{ha}{ }^{-1}+$ PSB inoculation. The organic manure FYM is known to be a very good source of available nutrients which released during mineralization. The $\mathrm{P}$ solubilizers on the other hand transforms fixed and insoluble forms of $\mathrm{P}$ into soluble forms and increase the availability of phosphorus. Similar results were also obtained by Khanday and Ali (2012) ${ }^{[5]}$.

On the basis of results, it was concluded that the application of 60 and $40 \mathrm{~kg} \mathrm{P}_{2} \mathrm{O}_{5} \mathrm{ha}^{-1}$ along with $5 \mathrm{t} \mathrm{FYM} \mathrm{ha}^{-1}$ found equally beneficial for yield and quality of mustard in Rajasthan and maintaining the fertility of soil.

Table 3: Effect of phosphorus, FYM and microbial inoculum on available nitrogen, phosphorus, potassium and sulphur in soil after harvest of mustard (Mean of 2 years)

\begin{tabular}{|c|c|c|c|c|}
\hline Treatments & Available N (kg ha' $\left.{ }^{-1}\right)$ & Available $\mathbf{P}\left(\mathrm{kg} \mathrm{ha}^{-1}\right)$ & Available K $\left(\mathrm{kg} \mathrm{ha}^{-1}\right)$ & Available $S\left(\mathrm{~kg} \mathrm{ha}^{-1}\right)$ \\
\hline \multicolumn{5}{|c|}{ Phosphorus levels $\left(\mathrm{P}_{2} \mathrm{O}_{5} \mathrm{~kg} \mathrm{ha}^{-1}\right)$} \\
\hline 0 & 255.17 & 19.07 & 289.46 & 8.87 \\
\hline 20 & 259.32 & 20.02 & 299.20 & 9.42 \\
\hline 40 & 263.81 & 20.73 & 305.66 & 9.76 \\
\hline 60 & 267.43 & 21.13 & 309.35 & 9.94 \\
\hline S.Em+ & 1.48 & 0.18 & 2.40 & 0.11 \\
\hline $\mathrm{CD}$ at $5 \%$ & 4.27 & 0.51 & 6.92 & 0.32 \\
\hline \multicolumn{5}{|l|}{ FYM levels (t ha-1) } \\
\hline 0 & 250.31 & 19.19 & 290.12 & 8.66 \\
\hline 5 & 272.49 & 21.29 & 311.71 & 10.34 \\
\hline S.Em+ & 1.05 & 0.13 & 1.70 & 0.08 \\
\hline CD at $5 \%$ & 3.03 & 0.36 & 4.90 & 0.22 \\
\hline \multicolumn{5}{|c|}{ Microbial inoculum } \\
\hline No inoculation & 258.20 & 19.34 & 294.97 & 9.28 \\
\hline PSB & 263.16 & 20.52 & 302.75 & 9.57 \\
\hline VAM & 259.41 & 20.16 & 298.91 & 9.52 \\
\hline PSB + VAM & 264.83 & 20.89 & 307.06 & 9.63 \\
\hline S.Em+ & 1.33 & 0.13 & 1.54 & 0.06 \\
\hline CD at $5 \%$ & 3.73 & 0.35 & 4.33 & 0.18 \\
\hline
\end{tabular}

Table 4: Effect of phosphorus and FYM interaction on available phosphorus and available sulphur of mustard (Mean of 2 years)

\begin{tabular}{|c|c|c|c|c|}
\hline \multirow{3}{*}{$\begin{array}{l}\text { Phosphorus levels } \\
\left(\mathrm{P}_{2} \mathrm{O}_{5} \mathrm{~kg} \mathrm{ha}^{-1}\right)\end{array}$} & \multirow{2}{*}{\multicolumn{2}{|c|}{$\frac{\text { Available phosphorus }\left(\mathrm{kg} \mathrm{ha}^{-1}\right)}{\text { FYM levels }\left(\mathrm{t} \mathrm{ha}^{-1}\right)}$}} & \multirow{2}{*}{\multicolumn{2}{|c|}{$\begin{array}{c}\text { Available sulphur }\left(\mathrm{kg} \mathrm{ha}^{-1}\right) \\
\text { FYM levels }\left(\mathrm{t} \mathrm{ha}^{-1}\right)\end{array}$}} \\
\hline & & & & \\
\hline & 0 & 5 & 0 & 5 \\
\hline 0 & 17.45 & 20.65 & 8.30 & 10.27 \\
\hline 20 & 18.79 & 21.21 & 8.78 & 10.36 \\
\hline 40 & 19.90 & 21.50 & 8.72 & 10.31 \\
\hline 60 & 20.50 & 21.70 & 8.84 & 10.41 \\
\hline S.Em+ & \multicolumn{2}{|c|}{0.25} & \multicolumn{2}{|c|}{0.09} \\
\hline $\mathrm{CD}$ at $5 \%$ & \multicolumn{2}{|c|}{0.72} & \multicolumn{2}{|c|}{0.25} \\
\hline
\end{tabular}


Table 5: Effect of FYM and microbial inoculum interaction on available phosphorus in soil after harvest of mustard (Mean of 2 years)

\begin{tabular}{|c|c|c|}
\hline \multirow{2}{*}{$\begin{array}{c}\text { Phosphorus levels } \\
\left(\mathbf{P}_{\mathbf{2}} \mathbf{O}_{\mathbf{5}} \mathbf{k g ~ h a}^{-1}\right)\end{array}$} & \multicolumn{2}{|c|}{ Available phosphorus (kg ha' } \\
& \multicolumn{2}{|c|}{ FYM levels $\left(\mathbf{t ~ h a}^{-\mathbf{1}}\right)$} \\
\hline & $\mathbf{0}$ & $\mathbf{5}$ \\
\hline No inoculation & 18.01 & 20.67 \\
\hline PSB & 19.41 & 21.50 \\
\hline VAM & 19.13 & 21.19 \\
\hline PSB + VAM & 20.09 & 21.70 \\
\hline S.Em+ & \multicolumn{2}{|c|}{0.18} \\
\hline CD at 5\% & \multicolumn{2}{|c|}{0.50} \\
\hline
\end{tabular}

\section{References}

1. Arbad BK, Ismail S. Effect of integrated nutrient management on soybean (Glycine max) - safflower (Carthamus tinctorius) cropping system. Indian Journal of Agronomy 2011;56:340-345.

2. Chesti MH, Kohli A, Sharma AK. Effect of integrated nutrient management on yield of and nutrient uptake by wheat (Triticum aestivum) and soil properties under intermediate zone of Jammu and Kashmir. Journal of the Indian Society of Soil Science 2013;61:1-6.

3. Chouksey H, Sardana V, Sharma P. Variability in Indian mustard (Brassica juncea) genotypes in response to applied phosphorus. Indian Journal of Agronomy 2017;62(3):374-377.

4. Gangwal TV, Patel MV, Jadhav NJ. Effect of phosphorus, sulphur and phosphate solubluzing bacteria on yield, nutrient uptake and soil fertility after harvest of mustard. Indian Journal of Fertilizer 2011;7:32-40.

5. Khanday AS, Ali N. Effect of different fertilizer and irrigation management systems on soil physico-chemical properties and pod yield of garden pea (Pisum sativum L.). Annals of Horticulture 2012;5(1):34-40.

6. Khandelwal R, Choudhary SK, Khangarot SS, Jat MK, Singh P. Response of cowpea [Vigna unguiculata (L.) Walp] to nitrogen and phosphorus fertilizers and seed inoculations. Legume Research 2012;35:235-238.

7. Kumar A, Bharati AK, Yadav S, Pandey HC, Kumar V. Influence of biofertilizer and farm yard manure on growth, yield and seed quality of Mustard (Brassica juncea L.) in rainfed condition. International Journal of Agricultural Science and Research 2017;7(2):197-202.

8. Lingaraju NN, Hunshal CS, Salakinkop SR. Effect of biofertilizers and foliar application of organic acids on yield, nutrient uptake and soil microbial activity in soybean. Legume Research 2016;39(2):256-261.

9. Luthura KL, Saha SK, Awasthi PK. Role of rock phosphate in present day agriculture. Indian Journal Agricultural Chemistry 1983;15:13-27.

10. Pathak J, Pal RL. Effect of integrated plant nutrient management on content and uptake of phosphorus by Indian Mustard. Progressive Agriculture 2016;16(1):6166.

11. Singh G, Kumar D, Sharma P. Effect of organics, biofertilizers and crop residue application on soil microbial activity in rice - wheat and rice-wheatmungbean cropping systems in the Indo-Gangetic plains. Cogent Geoscience 2015;1:1085296 http://dx.doi.org/ 10.1080/23312041.2015.1085296.

12. Solanki RL, Mahendra S, Sharma SK, Purohit HS, Arvind V. Effect of different level of phosphorus, sulphur and PSB on the yield of Indian mustard (Brassica juncea
L.) and soil properties and available macronutrients. Journal of Agricultural Science 2015;5(9):305-310.

13. Somani LL. Handbook of biofertilizer. Agrotech publishing academy, Udaipur 2004, 1168.

14. Tandon HLS. Phosphorous research and agricultural production in India. Fertility Development and Consultant Organization. New Delhi 1987.

15. Toro M. Phosphate solubilising microorganisms in the rhizosphere of native plants from tropical savannas: An adaptive strategy to acid soils/ In: Velaquez C, Rodriguez-Barrueco, E(eds). Developments in Plant and Soil Science. Springer. Netherlands 2007, 249-252. 